\title{
MODIN DAN OTORITASNYA: STUDI KASUS LARANGAN KAWIN HAMIL DI KELURAHAN TEMAS KOTA BATU
}

\author{
Mukhammad Nur Hadi' ${ }^{1}$, Khiyaroh ${ }^{2}$ \\ Magister Ilmu Syariah, UIN Sunan Kalijaga Yogyakarta \\ Email: hadinurmukhammad@gmail.com
}

\begin{abstract}
:
This study discusses the modin and its authority as the officers of the marriage registrar in Temas village. The focus of this study is the idea of banning pregnant marriage by modin. Pregnant women who want to marry are prohibited from doing marriage until she gives birth. This study is an empirical research of law by placing sociology of law as its approach. This research puts the theory of legal authority and reasoning in anlyzing data. Related to the theory of legal authority, the theory of Freidman and Khaled Abou el-Fadhl was chosen for legal sociology analysis. The three things which are focus of this study are about why did modin issue the policy, how is the policy authority position, and how did modin interpretation of article $53 \mathrm{KHI}$ related to the prohibition of pregnant marriage. First, this study shows that there are two major narratives (sociological reasons) of why modin should implement the idea; these are preventing stigmatization of free sex and preserving the lineage. Second, through the theory of autorithy, modin got three authorities at once; persuasive authority, traditional authority, and charismatic authority. Therefore, that policy automatically had the authoroty. Third, in constructing his idea, modin applied three interpretation methods; authentical interpretation, sociological interpretation, and historical interpretation.
\end{abstract}

Keywords: Modin, Authority, Pregnant Marriage

\begin{abstract}
Abstrak:
Kajian ini membahas tentang modin dan otoritasnya sebagai pegawai pembantu pencatat nikah di Kelurahan Temas. Fokus kajian ini adalah ide pelarangan kawin hamil oleh modin. Wanita hamil yang hendak menikah dilarang melaksanakan pernikahan sampai ia melahirkan. Kebijakan ini berlaku di seluruh keluruhan Temas. Kajian ini merupakan kajian hukum empiris dengan menempatkan sosiologi hukum sebagai pendekatannya. Penelitian ini menempatkan teori otoritas hukum dan penalaran sebagai pisau analisisnya. Terkait teori otoritas hukum, teori Freidman dan Khaled Abou el-Fadhl dipilih untuk analisis sosiologi hukum. Tiga hal yang menjadi fokus kajian ini adalah tentang mengapa modin mengeluarkan kebijakan tersebut, bagaimana posisi otoritas kebijakan tersebut, serta bagaimana penafsiran modin atas Pasal $53 \mathrm{KHI}$ terkait larangan kawin hamil. Kajian ini menunjukkan bahwa, pertama, ada dua narasi besar (alasan sosiologis) mengapa modin harus mengimplementasikan idenya, yaitu; untuk mencegah stigma legalisasi perzinaan dan menjaga kesucian nasab anak. Kedua, melalui perspektif teori otoritas, modin menempati tiga
\end{abstract}


otoritas sekaligus; otoritas persuasif, tradisional, dan kharismatik. Oleh karena itu, kebijakan yang digagasnya secara otomatis memiliki otoritas. Ketiga, dalam mengkontruksi pemikirannya, modin menggunakan tiga jenis penafsiran hukum; penafsiran secara otentik, sosiologis, dan historis.

Kata Kunci: Modin, Otoritas, Kawin Hamil

\section{PENDAHULUAN}

Polemik kawin hamil, dalam wacana hukum keluarga di Indonesia, setidaknya bermula dari klausul Pasal 53 Kompilasi Hukum Islam (KHI) Sebenarnya, celah pelaksanaan kawin hamil juga telah diatur oleh Undang-Undang Nomor 1 Tahun 1974 tentang Perkawinan. melalui pasal dispensasi perkawinan. Pada Pasal 7 ayat (2) dalam Undang-Undang Nomor 1 Tahun 1974 dijelaskan tentang kemungkinan terjadinya penyimpangan untuk menikah di bawah umur. Dalam konteks ini kawin hamil yang terjadi di bawah umur perkawinan yang telah ditetapkan, yang sekarang melalui Undang-Undang Nomor 16 Tahun 2019 umur pernikahan untuk laki-laki dan perempuan adalah 19 tahun bisa ter-cover melalui rumusan pasal ini.Sementara itu, munculnya KHI justru tampak memberikan peluang atas kemungkinan terjadinya pelanggaran itu melalui Pasal 53 yang secara khusus membahas ketentuan kawin hamil. Intinya, dalam pasal tersebut dijelaskan bahwa wanita yang hamil di luar nikah bisa menikah dengan siapa saja-tidak harus dengan yang menghamilinya. Karena itu, tentu pelaksanaan perkawinannyatidak perlu menunggu kelahiran anaknya dan perkawinan tersebut sudah dianggap sah.

Selain pemicu fenomena ini berasal dari wilayah yuridis, dominasi pemikiran hukum secara normatif, dalam konteks ini fikih, juga menjadi salah satu pemicunya. Dominannya paradigma fikih di masyarakat seringkali memunculkan celah-celah hukum yang dianggap legal karena fikih yang dianggap sebagai hukum agama dianggap mampu memberikan solusi atas rumitnya masalah. Dikotomi inilah yang sering berdampak pada pola penalaran hukum di masyarakat. Selama dalam fikih ada pendapat yang bisa menyelesaikan masalah, maka menjalankan pendapat tersebut bukanlah sesuatu yang tabu walaupun melanggar ketentuan hukum positif yang berlaku. Oleh karena itu, melakukan pernikahan sirri sebagai solusi dari kasus kehamilan sebelum nikah yang terjadi di bawah umur pernikahan tidak bisa sepenuhnya disalahkan (Muhammad Zaini dan Samidi, Ulama' kelurahan Temas, 13 Februari 2016).

Peran Hakim Pengadilan Agama untuk mengabulkan izin dispensasi perkawinan akibat hamil di luar nikah juga turut memicu polemik kawin hamil di masyarakat. Terkait hal ini, Inayah dalam 
kajiannya menemukan data menarik tentang hal ini. Inayahmenjelaskan bahwa dalam kurun waktu 2010-2015 terdapat 248 perkara permohonan dispensasi nikah di Pengadilan Agama Yogyakarta. Dari jumlah itu, 174 perkara (72\%) yang dipublikasikan di website Pengadilan Agama Yogyakarta berawal dari kasus hamil di luar nikah (Inayah, 2017: 179).

Pengabulan dispensasi nikah akibat kawin hamil ini setidaknya, dalam pengamatan Inayah, berdasar pada tiga aspek; hukum, sosial, dan moral atau agama. Memang, secara hukum pelaksanaan kawin hamil tidak melanggar ketentuan hukum terkait, seperti Undang-Undang tentang Perkawinan dan KHI. Selain itu, melalui dispensasi kawin, Hakim berpandangan bahwa cara ini bisa mencegah perbuatan zina, agar tidak terus-menerus dilakukan dan juga untuk melindungi janin (Inayah, 2017, 188). Cara inilah yang diklaim oleh hakim bisa mewujudkan kemaslahatan dan dianggap telah sesuai dengan amanat kaidah fiqh "daru' al-mafasid muqaddam 'ala jalb al-mas\}alih" (menolak kemudharatan lebih baik daripada mewujudkan kemaslahatan). Model penalaran hukum seperti inilah yang sering digunakan oleh Hakim dan hampir banyak bisa ditemui berbagai kasus permohonan dispensasi kawin. Namun, pertimbangan yang digunakan oleh hakim terkadang justru tidak sejalan dengan para pemangku otoritas di masyarakat.

Di saat terkadang hakim berusaha untuk memberikan dispensasi nikah, di Kelurahan Temas Kecamatan Batu Kota Batu, Jawa Timur, seorang Modin justru menolak tegas untuk menikahkan wanita hamil. Meskipun umur kehamilannya baru satu minggu. Proses pernikahan akan dibantu oleh Modinketika anak yang dikandung telah dilahirkan. Walaupun dalam kenyataannya beberapa masyarakat tidak setuju dengan prinsip tersebut, Lurah Temas, Aditya Prasaja, dan mayoritas masyarakat mendukung dan mensukseskan agenda modin tersebut. Prasaja bahkan menyatakan bahwa prinsip modin tersebut merupakan kearifan lokal yang wajib dihormati karena terpilihanya modin adalah hasil musyawarah di masyarakat. Ia juga menegaskan bahwa selama tidak ada laporan keberatan dari masyarakat atas gagasan prinsipal itu, pihak kelurahan juga tidak akan menegur (Prasaja, Lurah Desa,16 Maret 2016).

Kajian tentang kawin hamil secara umum banyak dilakukan, baik kajian secara normatif maupun emipiris. Oleh sebab kajian artikel ini bersifat empiris, maka penelusuran kajian pustaka sebagai pijakan orisinalitas tulisan lebih mengarah pada kajian yang membahas bagaimana hukum kawin hamil dipahami dan dipraktikkan di masyarakat.

Penelitian tentang pelarangan kawin hamil sebelumnya pernah dilakukan oleh Prihatin. Prihatin meneliti tentang praktik penundaan perkawinan bagi wanita hamil di Desa Mojorejo Kecamatan Junrejo Kota Batu. Perbedaan fundamental dengan kajian ini terletak pada perspektif 
yang digunakan. Jika kajian Prihatin lebih menitikberatkan pada tinjauan teori sadd az-zari'ah sebagai pisau analisis utama (Prihatin, 2011), maka kajian ini menempatkan teori otoritas hukum dan penafsiran hukum sebagai pisau analisisnya. Selain itu, fokus penelitian ini juga lebih kepada satu tokoh, modin, yang menginisiasi ide baru tersebut yang ini tentu tidak sama dengan kajian Prihatin yang fokusnya lebih lebar, yaitu pada kebijakan yang digagas oleh beberapa tokoh dan lintas organisasi masyarakat setempat, namun tidak mendalam.

Penelitian lain yang juga memiliki kedekatan dengan kajian ini juga pernah dilakukan oleh Prasongko. Penelitian yang dilakukan di Kebumen ini fokus pada pandangan tokoh agama di Kelurahan Panjer, Kecamatan Kebumen Kabupaten Kebumen terhadap aturan nikah hamil dalam KHI. Menariknya, hasil kajian ini menunjukkan bahwa nikah hamil menurut pandangan mayoritas tokoh agama di Panjen dilarang (Prasongko, 2012). Namun, kajian ini hanya sebatas memetakan pandangan-pandangan tokoh agama dan menguraikannya secara deskriptif.

Yustika dalam hasil kajiannya yang terfokus pada pandangan pihak KUA Kasihan Bantul, D.I. Yogyakarta tentang kawin hamil menunjukkan kesesuaian pandangan pihak KUA dengan Pasal 53 KHI (Yustika, 2014). Hasil kajian ini tidak lebih hanya tampak lebih memperkuat konsep kemaslahatan kawin hamil dalam Pasal 53 KHI.

Beberapa kajian di atas setidaknya bisa menjadi basis pelaksanaan penelitian ini. Jika beberapa penelitian di atas mengkaji pandangan beberapa tokoh dalam suatu komunitas, maka kajian tiga hal yaitu tentang mengapa Modin mengeluarkan kebijakan tersebut, bagaimana posisi otoritas kebijakan tersebut, serta bagaimana penafsiran Modin atas Pasal 53 KHI terkait larangan kawin hamil. Dalam konteks kajian ini, hal yang akan menjadi titik pengamatan peniliti adalah tentang otoritas Modin karena ini menyangkut legalitas dan area kewenangan seorang Modin yang kedudukannya hanya sebagai pembantu penghulu. Sisi lain yang hendak dipotret adalah bagaimana konstruksi pemikirannya.

\section{METODE PENELITIAN}

Penelitian ini adalah penelitian hukum empiris. Sedangkan pendekatan utama yang digunakan adalah pendekatan sosiologi hukum. Dalam kajian ini, teori otoritas hukum digunakan sebagai media untuk melihat konstruksi otoritas Modin dalam implementasi pemikirannya. Sedangkan teori penafsiran hukum digunakan sebagai kerangka teori untuk membaca pola berpikirnya, terutama dalam membaca pola penafsirannya terhadap aturan terkait yang dilibatkannya dalam bernalar. Uraian pada kajian mengacu pada peneletian yang telah dilakukan di Temas selama dua bulan yaitu Feberuari sampai Maret tahun 2016, data diperoleh melalui wawancara langsung kepada Modin, Lurah kelurahan 
Temas, dan Kepala Kantor Urusan Agama Batu. Sumber data primer adalah modin, kepala desa, bidan dan tokoh-tokoh desa Temas. Data sekunder yaitu publikasi yang terkait dengan tema penelitian, yaitu peraturan-peraturan tentang kawin hamil dan, peraturan-peraturan yang terkait kawin hamil di Indonesia.

\section{PEMBAHASAN}

\section{Kawin Hamil dalam Kajian Fikih dan Hukum Positif di Indonesia}

Dalam kajian fikih, pembahasan tentang hukum perkawinan wanita hamil terbagi pada dua kajian, yaitu perkawinan wanita hamil yang kehamilannya terjadi karena hubungan suami istri dalam ikatan perkawinan yang sah dan perkawinan wanita hamil yang kehamilannya disebabkan oleh hubungan seks di luar nikah. Untuk kategori yang pertama Jumhur ulama sepakat bahwa seorang wanita yang hamil dan ia berstatus cerai mati atau cerai talak tidak boleh dinikahi hingga anaknya meninggal. Sedangkan pada kasus kedua, Jumhur ulama pendapat berbeda tentang kebolehan atau larangan pernikahannya. Perbedaan pendapat ini didasarkan pada standar kemaslahatan yang digunakan.

Pada topik pernikahan wanita hamil karena hubungan di luar nikah, pembahasan juga terbagi lagi pada dua kategori, yaitu perkawinan wanita hamil dengan yang menghamilinya dan perkawinan wanita hamil dengan selain yang menghamilinya. Untuk kasus pertama Jumhur ulama' sepakat bahwa perkawinan mereka diizinkan karena wanita tersebut tidak memiliki masa 'iddah. Pada kasus ini, jika anak yang dikandung lahir ketika usia perkawinan enam bulan atau lebih (wanita tersebut dinikahi saat usia kandungan tiga bulan), maka nasab anak tersebut masih bisa disandarkan pada bapaknya. Namun, jika yang terjadi sebaliknya, maka nasab anak tersebut hanya bisa disandarkan pada ibunya (Zuhaili, 2006: 6648-6649).

Kasus berikutnya adalah pernikahan wanita hamil (wanita pezina) dengan orang yang bukan menghamilinya. Ulama empat mazhab, tentang hal ini, memiliki pendapat yang beragam.Dalam lingkup Hanafiyyah,Abu Hanifah, pengagas mazhab rasionalis ini, dan Muhammad, salah satu muridnya, sama-sama sepakat bahwa perkawinan wanita pezina yang hamil dengan orang lain diperbolehkan. Bahkan, jika wanita tersebut pun tidak hamil juga boleh dinikahi orang lain. Namun menariknya, kebolehan tidak semerta-merta bisa menghalalkan mereka untuk berhubungan suami istri. Abu Hanifah dan Muhammad menegaskan bahwa hubungan badan dilarang, sampai anak yang dikandung lahir (Zuhaili, 2006: 6648-6649).

Argumen mereka berdasar pada surat an-Nisa' ayat 24. Ayat ini menceritakan tentang wanita-wanita yang haram dinikahi. Kategori yang diuraikan berdasar pada sebab hubungan nasab, hubungan mushaharah, 
dan hubungan sepersusuan. Sedangkan wanita pezina, baik yang hamil atau tidak, bukan termasuk kelompok yang dimaksud sehingga hukum menikahinya menjadi boleh. Selain ayat ini, hadits tentang tidak ada kemulyaan bagi pezina juga dijadikan basis argumentasinya. Al waladu lil firasy, wa lil 'ahir al hijr. Ketika tidak kemulyaan bagi wanita pezina, maka menikahinya bukan merupakan larangan. Selanjutnya, mengenai ketidakbolehan menyetubuhinya hingga melahirkan berdasar pada hadis yang menarasikan bahwa seseorang dilarang menumpahkan air (mani) di ladang(rahim) yang bukan miliknya (Zuhaili, 2006: 6649). Bunyi narasi hadis itu adalah "man kana yu'minu billahi wa al-yawm al-akhiri fala yasqi maa'hu zar'a gairihi".

Masih dalam kerangka pemikiran ulama' Hanafiyyah, pandangan kedua terhadap topik ini datang dari Abu Yusuf dan Zufar. Mereka menyatakan bahwa wanita hamil akibat zina tidak boleh dinikahi. Argumennya adalah ketika kehamilan bisa menghalangi pernikahan, maka akad perkawinannya pun juga dilarang (Zuhaili, 2006: 6649). Ketika kehamilan wanita pezina terjadi karena hubungan terlaranga, maka apakah layak jika air mani seorang laki-laki yang masih "suci" disiramkan ke ladang (rahim) yang telah tercampuri oleh air mani dari hubungan terlarang (Sabiq, tt: 65).

Sementara itu, ulama Malikiyyah menyatakan bahwa perkawinan wanita hamil sebab zina tidak boleh menikah dengan orang yang tidak menghamilinya. Wanita tersebut bisa dinikahi ketika ia telah menyempurnakan istibra' (cara untuk mengetahui bersihnya kandungan) dengan cara menunggu kelahiran anak yang dikandung (Zuhaili, 2006: 6650). Jika terlanjur terjadi pernikahan sebelum istibara' berakhir maka akad pernikahan dianggap fasid (cacat) dan tentunya wajib dinasakh, baik wanita tersebut jelas kehamilannya atau masih prediktif (samar). Karena jika kehamilan wanita jelas dan dinikahi, maka berlaku hadis larangan menyiramkan air (mani) ke ladang yang bukan miliknya. Namun, jika kehamilan masih prediktif dan sudah dinikahi, perintah utuk memfasakh pernikahannya adalah kekhawatiran tercampurnya nasab (Zuhaili, 2006: 6650)

Dalam kajian fikih Syafi'i, wanita yang telah melakukan zina, baik akibat perbuatan tersebut ia hamil atau tidak, tanpa menunggu habisnya masa 'iddah; lahirnya bayi yang dikandung (Sabiq, tt: 65). Konsekuensinya adalah bahwa wanita tersebut boleh dinikahi oleh siapapun termasuk dengan orang yang belum pernah menggaulinya. Ketika mereka telah berada dalam ikatan perkawinan, laki-laki yang menikahi wanita tersebut juga boleh menyetubuhinya tanpa harus menunggu wanita tersebut melahirkan anaknya (Syirazi, tt: 43).

Tidak jauh berbeda dengan pendapat mazhab Malikiyyah, ulama' Hanabilah juga tidak mengizinkan pernikahan tersebut kecuali jika wanita 
hamil tersebut telah selesai masa 'iddah. Ulama' Hanabilah juga mensyaratkan taubat bagi wanita tersebut dari perbuatan asusilanya (zina) yang telah dilakukan sebelumnya jika hendak menikah (Zuhaili, 2006: 6650).

Kasus kawin hamil ini juga diatur dalam KHI pada Pasal 53. Dalam pasal tersebut dijelaskan bahwa seorang wanita hamil di luar nikah, dapat dikawinkan dengan pria yang menghamilinya. Artinya siapapun boleh menikah dengan wanita hamil di luar nikah. Kemudian, perkawinan dengan wanita hamil yang disebut dapat dilangsungkan tanpa menunggu lebih dulu kelahiran anaknya. Makna lain yang dapat ditangkap di sini adalah adanya kemungkinan untuk tidak melaksanakan atau melarang perkawinan hingga wanita melahirkan. Namun, KHI ternyata juga menegaskan bahwa jika perkawinan dilangsungkan pada saat wanita hamil, maka tidak perlu ada perkawinan ulang setelah anak yang dikandung lahir.

Kebolehan perkawinan wanita yang hamil diluar nikah telah ditetapkan oleh KHI, yaitu wanita yang telah hamil diluar nikah (zina) dapat dinikahkan dengan laki-laki yang menghamilinya. Atau kata "dapat" dalam Pasal 53 ayat (1) tersebut bisa diartikan boleh dinikahkan dengan laki-laki lain yang tidak menghamilnya. Dalam konteks laki-laki lain yang tidak meghamilinya tetapi mau untuk menikahinya, dikarenakan kehamilan tersebut terjadi karena pemerkosaan, maka jika wanita tersebut tidak diperbolehkan melaksanakan perkawinan tentu akan menimbulkan dampak psikologis bagi wanita tersebut dan bagi keluarganya (Aladin, 2017: 244). Aturan kebolehan kawin hamil yang terdapat dalam KHI Pasal 53 ini tentu menghasilkan perbedaan dan perdebatan dari berbagai kalangan.

Terkait polemik aturan ini, Yahya Harahap berargumen bahwa diperbolehkannya perkawinan wanita hamil dalam KHI merupakan hasil perenungan panjang terhadap perbedaan antara kajian normatif dan realitas di masyarakat. Ketika keduanya diperhadapkan atau dibandingkan ternyata ada masalah yang rumit. Di satu sisi dalam kajian fikih terjadi perdebatan antara yang melarang dan membolehkan. Sementara di sisi yang lain, ada fakta bahwa di masyarakat sudah terbiasa melakukan pernikahan wanita hamil. Untuk menemukan benang merahnya, para pakar akhirnya bernalar dengan prinsip teleologis (istislah). Para penyusun KHI meyakini bahwa kemaslahatan yang lebih besar akan diperoleh ketika kawin hamil diizinkan. Sebaliknya, kemudorotan akan dihasilkan jika kawin hamil dilarang. Harahap menambahkan bahwa salah satu tujuan diperbolehkannya kawin hamil adalah untuk memperoleh kejalasan hukum terhadap anak yang dikandung (Basri, 1999: 58). Alasan lain mengapa kawin hamil di perbolehkan adalah untuk memberikan kesempatan pada para praktisi di 
Pengadilan Agama-dan juga para praktisi hukum di luar pengadilan-agar bisa memberikan alternatif hukum baru yang lebih aktual dan rasional sehingga bisa lebih kontekstual dan adaptif (Basri, 1999:59).

\section{Biografi Modin Temas}

Samsul Hadi adalah seorang modin di kelurahan Temas, kota Batu. Dia adalah sosok figur publik di Desa Temas yang memiliki etika yang baik dan tentunya dalam praktiknya taat pada ketentuan agama (Muhammad Zaini, Ulama' keluarahan Temas, 13 Februari 2016). Hal ini bisa jadi merupakan kualifikasi penting di masyarakat Temas untuk menentukan kualitas dan kelayakan seorang modin, karena nilai-nilai keagamaan akan dianggap terinternalisasi dalam diri seseorang jika nilainilai itu telah menyatu dan termanifestasi dalam aktivitas kehidupannya, bukan hanya karena penguasaan keilmuan yang holistik. Pada akhirnya, internalisasi itu akan mewujudkan sebuah kerangka etika kehidupan seseorang, sehingga etika dan nilai religiusitas memiliki korelasi penting sebagai standar kualifikasi figur publik yang baik. Oleh karena itu, benarlah bahwa dari dua calon yang diajukan di masyarakat, Samsul dianggap lebih siap untuk menjadi Modin.Berdasar uraian ini, penulis dapat menyebutnya sebagai salah satu tokoh yang dianggap mampu dalam bidang ini.

Samsul Hadi mengenyam pendidikan dasar di SDN 01 Temas selama enam tahun, 1977-1983. Setelah itu, ia melanjutkan pendidik sekolah menengah tingkat pertamanya di SMPN 01 Batu selama tiga tahun, 1983-1986. Untuk sekolah tingkat selanjutnya, ia memilih SMAN 01 Batu sebagai tempat belajarnya selama tiga tahun, 1986-1989. Nyatanya, waktu 16 tahun yang ia gunakan untuk belajar belum memberikan kepuasaan pengetahuannya, terutama dalam bidang agama. Akhirnya, ia memutuskan untuk melanjutkan belajarnya di pondok pesantren. Lirboyolah yang kemudian menjadi tempat menimba ilmu keagamaan secara mendalam meskipun hanya dua tahun saja (Hadi, modin, 27 Maret 2016).

\section{Modin dan Otoritasnya}

Modin dalam kamus besar Bahasa Indonesia diartikan sebagai juru azan; muezzin; pegawai masjid. Modin berasal dari bahasa arabmu'addzin yang digunakan sebagai sebutan orang yang menyuarakan adzan. modin juga dimaknai sebagai seseorang yang mempunyai tugas dibidang administrasi agama untuk membantu penghulu dalam hal upacaraupacara keagamaan (Syahbuddin, 2000: 190). Modin pada abad ke-19 di daerah Jawa berperan untuk menunjuk pejabat keagamaan di tingkat desa satu tingkat dibawah penghulu. Urusan-urusan keagamaan yang ditangani modin antara lain seperti membantu mempersiapkan pernikahan, menemani pengantin wanita dan pria ke penghulu, 
memimpin acara-acara yang berkaitan dengan kelahiran bayi dan juga mengurus jenazah (Mulyosari, 2007: 136)

Dalam praktiknya, seringnya, Modin ternyata juga sekaligus sebagai Pembantu Pegawai Pencatat Nikah (P3N). P3N merupakan anggota masyarakat tertentu yang diangkat oleh Kepala Kantor Kementrian Agama kabupaten/kota setempat untuk membantu tugastugas Pegawai Pencatat Nikah/Kepala KUA (PPN) di desa atau kelurahan tertentu (PMA Nomor 11 Tahun 2007: Pasal 1 ayat 4). Anggota masyarakat yang dimaksud adalah pemuka agama di kelurahan setempat yang ditunjuk untuk melakukan pembinaan kehidupan beragama Islam, berkoordinasi dengan instansi terkait dan lembaga yang ada dalam masyarakat. Hal ini dilakukan setidaknya untukmembantu kelurahan dalam mengorganisir masyarakat, terutama mengenai hal-hal yang berkaitan dengan agama, agar kehidupan beragama penduduk terpelihara dengan baik (Ilmiati dan Hasanah, 2017: 157). Dengan demikian, fungsi P3N sangat urgen bagi masyarakat dalam pelaksanaan pra-nikah dan peran $\mathrm{P} 3 \mathrm{~N}$ penting dalam rangka pemerataan pelayanan agama Islam terutama mengenai urusan pelayanan pernikahan di masyarakat.

P3N mendapatkan legalitas dari menteri Agama dengan jabatan sebagai pengantar orang yang hendak melaksanakan pernikahan atau rujuk serta sebagai pembina kehidupan beragama di kelurahan setempat. Bahkan terkadang mendapatkan tugas lain seperti melakukan pengawasan secara langsung terhadap pelaksanaan nikah dan rujuk yang terjadi di kelurahannya dan melaporkan pelaksanaannya kepada penghulu (PPN) Di samping itu tugas P3N juga membantu PPN dalam urusan kehidupan beragama, serta menjadi ketua BP4 di Kelurahan dan bertugas memberi nasihat perkawinan.Namun, Setelah turunnya Surat Edaran dari Kementrian Agama Nomor: kw.06.02/1/kp.01.2/160/2015 tentang Pelaksanaan Instruksi Dirjen Bimas Islam Nomor DJ.II/I Tahun 2015 tentang Pengangkatan Pembantu Pegawai Pencatat Nikah (P3N), maka tugas P3N dihapuskan dan menyerahkan sepenuhnya urusan pernikahan menjadi tanggung jawab penuh Kepala KUA. Dalam peraturan tersebut tidak dijelaskan secara terperinci mengenai porsi, hak, dan peran serta P3N dalam urusan pernikahan, sehingga tidak ada kejelasan mengenai nasib serta kedudukan P3N tersebut. Meskipun demikian, keberadaan modin yang sekaligus sebagai P3N tetap dibutuhkan dan dianggap tetap eksis, bukan hanyakarena historisnya yang melekat dengan kehidupan keagamaan masyarakat, tetapi juga karena fungsi, tugas, dan kredebilitasnya yang telah diterima masyarakt meskipun tidak secara an sich. Hal ini juga yang terjadi di Kelurahan Temas. 


\section{Ide Dasar Pelarangan Kawin Hamil}

Munculnya sebuah ide selalu dilatar belakangi oleh konteks sosial. Dinamika sosial itulah yang mampu memotivasi seorang pemikir atau pemegang otoritas untuk menemukan cara terbaik menghadapi perubahan yang mungkin bisa mengancam nilai-nilai moralitas, agama, hingga kebudayaan. Dalam konteks kajian ini, hasil wawancara peneliti menunjukkan bahwa ada dua narasi besar yang diangkat oleh modin dalam mengkonstruksi ide tersebut. Dua narasi besar yang ia angkat yaitu (1) mencegah stigma legalisasi perzinaan dan (2) menjaga kesucian nasab anak dimana keduanya merupakan kategori narasi aatau alasan yang bersifat sosiologis

Narasi pertama, saat Samsul ditanya mengapa ia berani mengambil langkah ini, ia menjelaskan bahwa munculnya stigma itu setidaknya berawal dari ketidakjelasan atau ambiguitas klausul Pasal 53 KHI yang memberikan banyak multi tafsir. Pasal itu sering digunakan sebagai alasan untuk melaksanakan kawin hamil sehingga yang terjadi adalah ada bentuk celah hukum yang kemudian dimanfaatkan oleh-oleh orang-orang yang mengalami masalah kehamilan di luar nikah (Hadi, modin, 6 Februari 2016).

Ketika kemudian Modin tetap melaksanakan untuk membantu pelaksanaan perkawinan mereka maka yang terjadi adalah ada bentuk dakwah kepada masyarakat. Mereka, menurut modin, akan dakwah kepada yang lain dengan mengatakan kepada teman-temannya bahwa hamil dahulu sebelum nikah tidak masalah karena akhirnya dinikahkan juga. Kemudian, apakah dengan hanya mendapatkanbuku nikah semua permasalahan selesai? Jawabannya tentu tidak. Ada dampak yang lebih besar dari hanya sekedar mendapatkan buku menikah. Modin memprediksi jika ia tetap untuk membantu menikahkan maka tidak menutup kemungkinan dalam satu tahun ke depanini anak yang lahir di Temasadalah anak yang lahir di luar nikah. Inilah yang menurut Modin dapat mengawali lahirnya justifikasi legalisasi perzinanaan atau seks bebas (Hadi, Modin, 6 Februari 2016).

Memang benar bahwa ada perbedaan pendapat tentang pernikahan wanita hamil. Namun, Modin menegaskan bahwa dalam hal terjadi perbedaan pendapat seseorang harus mengambil pendapat yang menurut pandangan seseorang tersebut memberikan kemaslahatan untuk konteks sosialnya. Oleh sebab itu ia cenderung memilih pendapat yang tidak membolehkan kawin hamil sampai anak yang dikandungnya dilahirkan (Samsul Hadi,Modin, 6 Februari 2016). Dalam konteks ini, peneliti memahami bahwa pendapat yang diikuti oleh Modin adalah pendapat Malikiyyah.

Alasan kedua, mengapa ia tetap bersikukuh untuk tetap mempraktikkan idenya di masyarakat adalah untuk menjaga kesucian 
nasab. Modin sesungguhnya khawatir jika kawin hamil terjadi apakah puluhan tahun mendatang ketika anak yang terlahir dari hubungan di luar nikah akan menikah, orang tua akan menjelaskan tentang asal usul kelahirannya? Bukankah orang tua tidak mempunyai hak menjadi wali nikah untuk anak hasil hubungan luar nikah? Kemudian, ketika orang tua biologis tidak bisa menjadi wali nikah, bagaimana hukumnya pernikahan nanti jika tetap dilaksanakan? Bukankah pernikahannya menjadi tidak sah? (Hadi, Modin, 6 Februari 2016). Melalui pertanyaan-pertanyaan inilah Modin menarasikan kekhwatirannya. Pembacaan Modin terhadap realitas mengarah jauh ke depan. bahwa anaknya adalah hasil hubungan di luar nikah. Memang benar, jika hal demikian terjadi, secara dhahirnya anak tetap dianggap sebagai anak sah secara hukum yang berlaku di Indonesia, karena anak lahir dalam ikatan perkawinan.

Di posisi ini, meskipun Modin menguraikan alasannya dalam kacamata sosiologis, landasan atau rujukan yang digunakan adalah fikih. Dalam hal menentukan larangan pernikahan wanita hamil, kecenderungan pemikirannya mengarah ke pendapat Malikiyyah. Sementara dalam hal upaya menjaga keucian nasab, ia lebih cenderung pada pendapat Syafi'iyyah yang menjadi mazhab dominan di Indonesia. Pola ekletisme pendapat ini terlihat dipandang lebih memberikan kemaslahatan.

\section{Otoritas Pemikiran Modin}

Secara resmi, gagasan modin ini diberlakukan di masyarakat sejak awal tahun 2015. Gagasan yang berubah menjadi sebuah aturan tak tertulis ini mulai berlaku ketika modin mengumumkannya di depan publik, tepatnya ketika ia sedang mengawal proses pengurusan jenazah dan pemakan masyarakat di rumah duka. Cara ini ditempuh karena dianggap efektif untuk menyebarkan informasi secara cepat. Selain itu, ia juga berkali-kali menyampaikan dan menekankan tentang aturan ini di pengajian-pengajian Muslimat dan laki-laki, dan juga acara pernikahan. Bahkan terkadang modin juga sesekali melakukan pendekatan secara personal untuk menyatakan pemberlakuan idenya itu, secara face to face, terutama kepada ibu-ibu karena dianggap memiliki perhatian lebih terhadap kegiatan anaknya (Hadi, Modin, 6 Februari 2016).

Modin memahami bahwa agar implementasi idenya itu berjalan dengan baik ia pada akhirnya mewajibkan kepada siapapun yang hendak menikah agar mencantumkan surat keterangan hamil dari dokter, bidan, puskesmas, atau klinik kesehatan di desa setempat sebagai syarat baru administrasi pernikahan di wilayah kerjanya. Jika calon pasangan yang hendak menikah tidak melengkapi syarat ini, maka berkas akan ditolak. Demikian juga ketika diketahui bahwa calon pengantin perempuan telah hamil, berkas juga akan ditolak (Hadi, Modin, 6 Februari 2016). Salah satu 
bidan di puskesmas kelurahan Temas juga menyatakan bahwa ia beberapa kali melakukan pemeriksaan kehamilan calon pengantin sejak Samsul Hadi menjadi modin. Baginya, apa yang dilakukannya merupakan kontribusi besar untuk membantu modin mensukseskan ide progresifnya karena tanggung jawab yang diemban oleh Modin sangat besar (Anwari Putri, Bidan Puskesmas, 16 Maret 2016).

Kondisi demikian sesungguhnya tidak semerta-merta bisa menghalangi para calon pengantin untuk mengurus pernikahannya. Mereka bisa saja datang langsung ke KUA. Namun, menariknya, pihak KUA setempat juga memahami bahwa di Temas terdapat sebuah konsesus publik tentang larangan kawin hamil. Oleh sebab itu, bagi kepala KUA Batu, terobosan baru yang dirancang oleh modin Temas merupakan langkah progresif yang patut didukung (Prasaja, Lurah Desa, 16 Maret 2016). Dari sinilah bisa dipahami bahwa pihak KUA sendiri memberikan kewenangan kepada Modinuntuk mengatur dengan baik sesuai dengan kesepakatan bersama tentang kawin hamil untuk menciptakan kemaslahatan.

Pada konteks inilah kesepakatan menjadi sebuah konsensus publik yang bisa mengikat walaupun tidak tertulis. Model kesepakatan ini bisa disebut sebagi bentuk 'urf karena publik telah memahami dan mengerti konsep yang dirumuskan. Selanjutnya, ketika 'urf ini dipraktikkan berulang kali, kemudian, ia bisa berubah menjadi'adah (kebiasaan) di masyarakat. Merujuk pada salah satu kaidah fikih yang menyatakan bahwa kebiasaan bisa menjadi hukum (al-'adah muhakkamah), maka kesepakatan yang mewujud tersebut bisa dianggap sebagai sebuah produk hukum lokal. Di sinilah modin memperoleh pijakan aksiologinya sebagai salah satu pemangku otoritas. Selain otoritasnya yang telah dipercaya oleh masyarakat dalam mengurus kegiatan keagamaan, kesepakatan ini justru semakin mengukuhkan dirinya memiliki wewenang lebih untuk mengontrol alur pernikahan di mana ia tinggal.

Otoritas modin yang kokoh ini, pada mulanya, bisa dikategorikan sebagai bentuk otoritas kharismatik. Otoritas ini, menurut Friedman, ada karena tunduknya masyarakat pada sebuah kharisma (Friedman, 2013: 149), yang dalam konteks ini kharisma seorang modin sebagai salah satu tokoh publik yang dipercaya oleh masyarakat dalam mengemban tugas mengurus urusan perkawinan ini kare pemikiran, kepribadian, serta tindakan yang dihormati.

Namun, seiring berjalannya waktu dan implementas kesepakatan tadi, otoritas Modin dalam konteks ini bisa berkembang menjadi otoritas tradisional (Friedman, 2013: 149). Artinya, ketundukan masyarakat tidak lagi hanya sebatas pada sosok atau figur seorang modin, tetapi lebih cenderung kepada adat atau kebiasaan yang telah terbangun berdasar pada kesepakatan bersama. 
Jika merujuk pada model otoritas dalam pandangan Khaled Abou al-Fadl, otoritas modin ini bisa disebut sebagai otoritas persuasif. Otoritas jenis ini berdasar pada kemampuan untuk mengarahkan keyakinan dan perilaku orang lain atas dasar kepecayaan. Kecenderungannya adalah lebh normatif karena lebih terkait dengan pengetahuan seseorang (alFadhl, 2001: 50). Pada konteks ini, modin dipandang sebagai sosok yang mampu mengubah alur dan pola pikir masyarakatnya terhadap kasus kawin hamil berdasar pada hasil penelaahannya. Hal lain yang membuat kokoh otoritas modin dalam mengimplementasikan idenya adalah karena wujud kebutuhan masyarakat terhadap modin di masyarakat. Segala hal yang diinisasinya secara mayoritas bisa diterima dengan baik karena adanya ikatan antara Modin sebagai pembantu penghulu dan masyarakat berdasar pada prinsip penghargaan atas ilmu agama (Halili, 2019: 69).

Pada konteks ini, apa yang digagas oleh modin sebagai bentuk upaya untuk memecahkan problematika sosial bisa dianggap sebagai upaya implementasi paradigma fikih sosial. Ia telah berusaha menunjukkan bahwa fikih berguna sebagai agen perubahan sosial (Abdullah, 2016: 86). Di sisi lain, modin sebenarnya telah membuktikan internalisasi doktrin hukum dalam dirinya melalui munculnya gagasan ini, karena doktrin dalam kajian sosiologi hukum tidak hanya berada dalam tataran ide saja. Lebih dari itu, doktrin mewujud dan terbentuk dalam tindakan sosial (Cotterrell, 2012: 61). Dengan begitu, cara pandang baru yang digunakannya terhadap persoalan kontemporer tersebut bisa menempatkannya sebagai praktisi fikih sosial yang cenderung menggunakan kerangka fikih dalam memandang persoalan sosial.

\section{Penalaran Hukum Modin: Membaca Interpretasi Modin}

Selain melihat landasan ide dan otoritasnya, pengamatan terhadap konstruksi penalaran hukum juga menjadi bagian yang bisa dianggap inheren dalam kerangka kajian pemikiran. Penelusuran ini dilakukan karena dari hasil wawancara, Modin melibatkan penafsiran atau pemahamannya terhadap KHI Pasal 53. Sebab itulah, menelusuri penggunaan jenis penafisarannya.

Model penalaran hukum modin sangat berkaitan erat dan dipengaruhi oleh sudut pandangan yang ia bangun. Shidarta menyatakan bahwa pola penalaran hukum selalu beriringan dan menyatu dengan sudut pandang atau perspektif dari subjek yang melakukan penalaran hukum. Elaborasi sudut pandang atau perspektif inilah yang kemudian bermuara menjadi orientasi berpikir yuridis yang termanifestasi dalam bentuk atau model penalaran dalam disiplin hukum, yang sebagaimana akhirnya dikenal sebagai aliran filsafat hukum (Shidarta, 2013: 126). Ada banyak dialektika keilmuan yang melatari gagasan besarnya. Lebih dari itu, pengamatannya yang jeli serta aduan-aduan keresahan masyarakat 
yang didengarnya bisa jadi merupakan beberapa pemicu konstruksi perspektifnya artinya segala hal tentang ide modin selalu berkaitan pada dua aspek, yaitu pertama, kualitas keilmuan dan preferensi pengembagan keilmuan, dan kedua, latar sosiologis yang mengitari kehidupannya.

Pada konteks ini juga bisa ditarik teori tentang sociology of knowledge (sosiologi pengetahuan). Terbentuknya ilmu pengetahuan-dalam hal ini perspektif dan nalar hukum modin-tidak bisa terlepas dari kondisi sosial. Keilmuan akan selalu mengikuti perkembangan kondisi sosial. Itulah mengapa melalui kacamata keilmuan ini penting untuk mengetahui bagaimana cara seorang pembaca hukum, modin, memperoleh pengetahuannya (Fanani, 2010: 64). Maksudnya, dalam kerangka teori sosiologi pengetahuan, pemahaman hukum modin terhadap fenomena kawin hamil bisa jadi akan terus berdinamika sesuai dengan konteks sosialnya. Jika saat ini ia tampak bersikukuh untuk melarang pernikahan wanita hamil, bisa jadi suatu saat ia akan mengubah pandangan itu dengan paradigma lain yang bisa jadi lebih bermaslahat. Hal ini dikarenakan adanya perubahan kondisi sosial di masyarakat ditambah dengan kemajuan keilmuan.

Dalam kajian hukum, ada beberapa model penalaran yang dirumuskan oleh para pakar. Shidarta menjelaskan bahwa secara garis besar ada dua pendekatan penalaran hukum, yaitu pendekatan tekstual (the textualist approach) dan pendekatan berbasis tujuan (the purposive approach). Jenis penalaran yang masuk pada kategori textualist approach adalah penalaran otentik (subsumptif) dan penalaran gramatikal. Sedangkan, jenis penalaran yang masuk pada jenis kedua meliputi penalaran sosiologis atau telelogis, penalaran sistematis atau logis, penalaran historis, penalaran komparatif, penalaran futuristis atau antisipatif, penalaran restriktif, dan penalaran ekstensif (Shidarta, 2013: 171). Mukti Arto menambah model beberapa penalaran lain yang menurut peneliti sering digunakan oleh para praktisi hukum, yaitu penalaran argumentum peranalogian (qiyas), penalarandan argumentum a contrario (mafhum mukhalafah) (Arto, 2018, 272-273). Ragam jenis inilah yang kemudian akan peneliti gunakan untuk mengamati jenis interpretasi yang digunakan oleh modin terhadap aturan kawin hamil. Penelusuran ini penting untuk menemukan sisi-sisi progresifitas penalaran hukum sekaligus sisi-sisi stagnasinya.

Berdasarkan hasil wawancara, peneliti menemukan beberapa kecenderungan penalaran hukum yang digunakan oleh modin. Pada wilayah penafsiran yang cenderung tekstual, modin menggunakan satu jenis penafsiran, yaitu, pertama, penafsiran otentik (bernalar secara bayani). Sedangkan, pada wilayah penafsiran bercorak kontekstual, ia melibatkan dua kerja penafsiran, yaitu penafsiran historis dan penafsiran secara 
sosiologis atau teleologis (bernalar secara istislahi dalam perspektif hukum Islam).

Penafsiran otentik dapat dilacak pada pemahaman modin yang tekstual. Ketika modin mengatakan Pasal 53 KHI itu memperbolehkan [kawin hamil]", maka sesungguhnya ia telah menggunakan penafsiran secara otentik. Ia menjelaskan kemungkinan yang terjadi dari klausul pasal tersebut. Oleh karena itu, ketika modin memahami pasal ini secara apa adanya, sesuai bunyi teks, maka bisa jadi Modin akan mengukur fakta lapangan dengan premis dalam pasal ini. Pada akhirnya, ia menyatakan bahwa banyaknya kawin hamil yang justru sering menimbulkan mafsadat adalah karena menurutnya sebab- ketegasan klausul Pasal 53 KHI yang membolehkan kawin hamil. Hal yang terdeteksi berikutnya sebab ketegasan pasal ini adalah wujudnya klaim legalisasi perzinahan yang hal ini menjadi salah satu motivasinya untuk memunculkan larangan kawin hamil.

Penafsiran sosiologis terhadap Pasal 53 dalam KHI mengacu pada kekhawatirannya terhadap meluasnya stigma masyarakat atas legalisasi kawin hamil sebagai media sah untuk berhubungan sebelum nikah menjadi pijakan paradigmatiknya dalam mengkonsepsikan kemudharatan. Modin juga beralasan justru dengan melakukan pencegahan terhadap kawin hamil tersebut kesucian nasab akan lebih terjaga yang tentu akan berdampak pada praktik perkawinan di tahuntahun mendatang.

Pertimbangan nalar hukum itu akhirnya memunculkan tandingan konsep maslahat. Perbedaan konsep kemaslahatan inilah yang perlu dipertegas. Jika para perumus KHI menganggap bahwa dengan melegalkan kawin hamil akan memberikan kemaslahatan yang besar untuk anak dan wanita, maka tidak demikian dengan Modin. Ia justru menganggap apa yang telah dirumuskan dalam KHI lebih menyisakan banyak kemudhorotan.Membolehkan nikah hamil justru dipandang sebagai sesuatu yang tidak memiliki basis kemaslahatan, karena sepanjang pengamatannya jumlah pernikahan wanita hamil lebih banyak terjadi sebelum ia menerapkan idenya sebagai kesepakat publik.

Sebaliknya, ia menemukan bahwa semenjak ia secara tegas menjalankan kesepakatan itu jumlah pernikahan wanita hamil di Temas dalam pengamatannya mengalami penurunan. Meskipun ia tidak melakukan penghitungan secara pasti, ia memperkirakan bahwa menurutnya bisa jadi perbandingannya dari sepuluh wanita yang menikah hanya satu orang yang telah hamil lebih dahulu. Ia menegaskan bahwa jumlah ini tentu jauh lebih sedikit dari tahun-tahun sebelum ia menerapkan kesepakatan itu dan sebelum terpilih menjadi modin (Hadi, Modin, 6 Februari 2016). Inilah alasannya mengapa kemaslahatan 
kesepakatan itu dianggap lebih jelas oleh modin daripada mengikuti konsep kemaslahatan kawin hamil dalam KHI.

Alur nalar hukum modin ini sebenarnya lebih kepada menghilangkan kemudharatan dengan cara melarang kawin hamil. Namun, modin akhirnya memahami konsep ini sebagai pemicu lahirnya maslahat. Menikahkan wanita memang bisa jadi media mewujudkan maslahat, tetapi hal ini tidak bisa berarti demikian bagi modin. Sebaliknya, ia menempatkan pernikahan wanita hamil sebagai bentuk kemudharatan yang nyata karena itu ia bersikukuh untuk menghentikannya.

Cara modin memahami kasus ini, dalam kajian maqashid syari'ah, menunjukkan upaya nalar berbasis sistem. Maqashid berbasis sistem tidak menempatkan level kepentingan yang menjadi prioritas, tetapi ia lebih menitikberatkan pada bagaimana sebuah nilai itu saling mempengaruhi (interrelationship) terhadap yang lain. Layaknya sebuah sistem, terhentinya sebuah komponen dalam sistem akan menghambat seluruh kinerja komponen yang lain (Auda, 2015: 89). Demikian juga halnya dalam nilai atau norma. Ketika suatu norma tidak tercapai implementasinya maka norma lain turut akan terhenti.Modindi Kelurahan Temas menganggap bahwa wanita yang hamil diluar nikah telah menyalahi sistem nilai atau norma agama dengan berbuat zina. Sehingga pelanggaran nilai yang dilakukan tidak dapat mengantarkannya pada tindakan pernikahan. Kebolehan wanita hamil tanpa adanya perkawinan terlebih dahulu (zina) dinikahkan dengan laki-laki yang mengahamili atau laki-laki lain, dalam perspektif maqashid bukanlah prioritas utama.

Dalam kajian hukum, penalaran hukum Modinini bisa disebut dengan penalaran hukum sosiologis atau teleologis. Konsep law as a tool of social engineering dari Rescue Pond berlaku pada kasus ini. Hanya saja hukum yang terbentuk pada konteks ini bukan merupakan hukum yang terbentuk dari penguasa dan diakui sebagai hukum yang diakui oleh negara. Hukum yang dibentuk merupakan produk kesepakatan secara bersama untuk kepentingan lokal yang akhinya menjadi nilai-nilai lokal yang wajib dihormati bagi seluruh penduduk lokal. Pengaturan masyarakat lebih ditonjolkan sebagai media untuk merealisasikan maslahat.

Kegelisahan Modin terhadap Pasal 53 KHI yang kemudian terjawab oleh ragam pendapat fikih, membuatnya berani untuk menetapkan pelarangan nikah hamil.Pada posisi ini bisa ditarik nalar berpikir hukumnya yang cenderung ekletik. Meskipun pada dasarnya ia lebih terpengaruh oleh figh Syafi'i, namun untuk kasus ini ia tidak semerta-merta mengaplikasikan nalar hukum Syafi'iyyah-mazhab yang menjadi pedoman ritualnya-pada kasus kawin hamil. 
Memang benar bahwa Syafi'iyyah secara eksplisit menegaskan bahwa pernikahan perempuan hamil sebab hubungan badan di luar nikah diperbolehkan dan diperbolehkan juga untuk menyetubuhinya. Pernikahanpun juga tidak menjadi masalah jika wanita tersebut menikah dengan lelaki yang tidak menghamilinya. Namun faktanya, tampaknya pendapat Modin tidak memiliki kecenderungan pada argumen Syafi'iyyah. Ia justru tampak lebih memihak pada pendapat Malikiyyah yang melarang menikahi wanita hamil sampai ia melahirkan. Sementara itu, pendapat Malikiyyah tentang keharusan wanita hamil untuk dinikahi oleh yang menghamilinya terlihat tidak diadaptasi oleh Modin dalam gagasannya. Di sinilah tampak jelas bahwa modin lebih cenderung melihat esensi sebuah pendapat yang baginya bisa berdampak baik untuk masa depan. Bahkan, apa yang dipilih modin sebagai basis argumen menjadi indikasi bahwa ia memahami sebuah konsep kontinuitas dan perubahan (continuity and change). Ia menunjukkan pada publik bahwa dalam menghadapi dinamika realitas sosial, konsep kontinuitas dan perubahan berelevansi penting untuk merespon kenyataan yang ada.

Inilah model penalaran historisnya yang tampak menggambarkan perdebatan fikih klasik yang menjadi acuan dasar penyusunan KHI. Penalaran historis ini terbaca ketika ia menyatakan penyesalannya "mengapa klausul di KHI berbunyi demikian" yang ini mengindikasikan pemahamanya pada adanya perdebatan pemikiran dan politik dalam proses perumusan KHI.

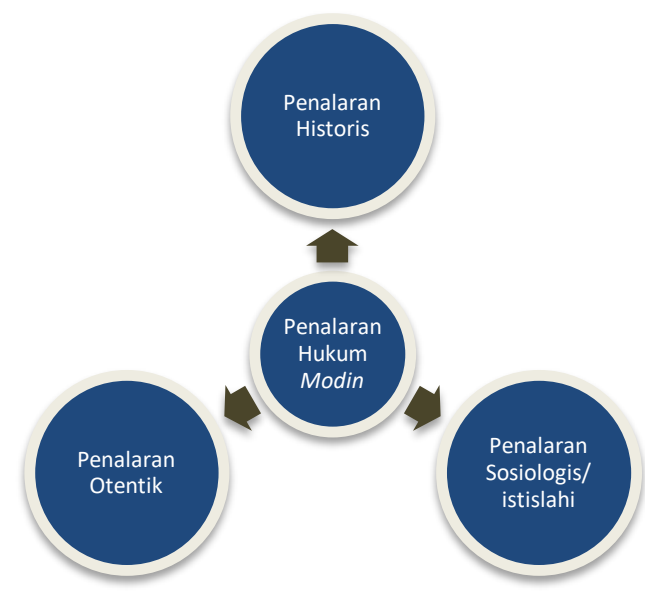




\section{SIMPULAN}

Hasil kajian ini menunjukkan bahwa ada dua narasi yang digunakan oleh modin dalam mengkonstruksi pemikirannya, yaitu ; pertama, mencegah pandangan legalisasi perzinaan yang berkembang di masyarakat dan, kedua, menjaga kesucian nasab. Dua narasi ini tentu dilatari oleh kondisi sosial yang dalam pengamatannya perlu segera dilakukan perubahan secara bertahap karena itu narasi ini bisa disebut dengan alasan berperspektif sosiologis.

Keberhasilan implementasi pemikiran modin dipengaruhi oleh kokohnya otoritas yang terbangun di masyarakat, yaitu otoritas kharismtik, otoritas tradisional, dan otoritas persuasif. Otoritas kharismatik terbangun karena modin berposisi sebagai salah satu tokoh publik yang dipercaya oleh masyarakat dalam mengemban tugas mengurus urusan perkawinan ini yang berdasar pada pemikirannya, kepribadiannya, serta tindakannya yang dihormati. Otoritas tradisional muncul karena ketundukan masyarakat tidak lagi hanya sebatas pada sosok atau figur seorang modin, tetapi lebih cenderung kepada adat atau kebiasaan yang telah terbangun berdasar pada kesepakatan bersama. Sedangkan otoritas persuasif terbentuk karena berdasar pada kemampuannya untuk mengarahkan keyakinan dan perilaku orang lain atas dasar kepecayaan keagamaan ia memperoleh legitimasi dari masyarakat.

Kajian ini juga menemukan beberapa jenis interpretasi modin yang digunakan dalam menyusun kerangka pemikirannya yang mengacu pada Pasal 53 KHI, yaitu penafsiran otentik, sosiologis, dan historis. Penalaran otentik terjadi saat modin memahami kebolehan kawin hamil pada Pasal 53 yang akan berdampak pada kerancuan nasab. Penalaran sosiologis tergambar pada pemikirannya yang bermuara pada perbedaan pertimbangan kemaslahatan pada pasal kawin hamil dalam KHI. Penalaran ini juga terlihat pada bagaimana ia memandang masa depan generasi saat ini dalam konteks perkawinan, jika kawin hamil masih saja dilegalkan. Sementara itu, penalaran historis terbaca ketika ia menyatakan penyesalannya tentang mengapa klausul di KHI megizinkan kawin hamil. Hal ini mengindikasikan adanya pemahaman modin terhadap perdebatan pemikiran dan politk dalam proses perumusan KHI. Di sinilah ia terlihat sedang berusaha menggali fakta-fakta historis yang terjadi pada proses perumusan KHI. 
Modin dan Otoritasnya: Studi Larangan Kawin Hamil...

\section{DAFTAR PUSTAKA}

Al-Fadhl, Khaled Abou. Speaking in God's Name: Islamic Law, Authority, and Women. London: Oneworld Publications. 2001.

Asy-Syirazi, Abu Ishaq. Al-Muhazzab. Kairo: Dar al-Fikr.

Arto, Mukti. Penemuan Hukum Islam Demi Mewujudkan Keadilan. Yogyakarta: Pustaka Pelajar, 2018.

Abdullah, Amin. "Fikih dan Kalam Sosial di Era Kontemporer: Perjumpaan Sains Modern Meunju Fresh Ijtihad." Dalam Islam Nusantara: Dari Ushul Figh Hingga Paham Kebangsaan, editor Akhmad Sahal dan Munawir Aziz, 86. Bandung: Mizan, 2016.

Auda, Jasser. Membumikan Hukum Islam Melalui Maqasid Syariah. Dialihbahasakan oleh Rosidin dan Ali Abd al-Mun'im. Bandung: Mizan, 2015.

Az-Zuhaili, Wahbah. Ushul al-Figh al-Islamiy Wa Adillatuhu. Damaskus: Dar al-Fikr, 1986.

Basri, Cik Hasan. Kompilasi Hukum Islam dan Peradilan Agama dalam Sistem Hukum Nasional. Jakarta: Logos Wacana Ilmu, 1999.

Cotterrell, Roger. Sosiologi Hukum.Dialihbahasakan oleh Narulita Yusron. Bandung: Nusa Media, 2012.

Dian Andromeda Yustika, al-Ahwal, Vol. 7, Nomor 2 (2014). "Pandangan Pihak Kua Kasihan, Bantul, Yogyakarta Tentang Kawin Hamil"." al-Ahwal 7, no. 2 (2014): 165-180.

Friedman, Lawrence M. Sistem Hukum Perspektif Ilmu Sosial. Dialihbahasakan oleh M. Khozin. Bandung: Nusamedia, 2013.

Hadi, Samsul. (27 Maret 2016).

Hadi, Samsul. (6 Februari 2016).

Halili, Penghulu di Antara Dua Otoritas Fikih dan Kompilasi Hukum Islam:Studi Tentang Dinamika Penyelesaian Isu-Isu Hukum Perkawinan di Daerah Istimewa Yogyakarta. Disertasi. UIN Sunan Kalijaga Yogyakarta.

Inayah, Nurul. "Penetapan Dispensasi Nikah Akibat Hamil di Luar Nikah di Pengadilan Agama Yogyakarta Tahun 2010-2015: Analisis Hukum Acara Peradilan Agama." al-Ahwal 10, no. 2 (Desember 2017).

Prasaja, Aditya. (14 Maret 2016).

Prasongko, Gugat Budi, Nikah Hamil Dalam KHI Menurut Pandangan Tokoh Agama Kelurahan Panjer Kec. Kebumen Kab. Kebumen, Skripsi, UIN Sunan Kalijaga Yogyakarta.

Prihatin, Maziyatul H, Penundaan Perkawinan Bagi Wanita Hamil Ditinjau dari Metode Sadd Al-Dzari'a'ah: Studi di Desa Mojorejo Kecamatan Junrejo Kota Batu, Skripsi, UIN Maulana Malik Ibrahim Malang. 
Muhammad Nur Hadi, Khiyaroh

Putri, Anwari. (16 Maret 2016).

Sabiq, Sayyid. Figh as-Sunnah.Kairo: al-Fath\} Li al-I'la>m al-'Araby. -.

Samidi. (13 Februari 2016)

Shidarta. Hukum Penalaran dan Penalaran Hukum. Yogyakarta: Genta Publishing, 2013.

Zaini, Muhammad. (13 Februari 2016). 